\title{
Od bezpieczeństwa w internecie do obywatelstwa cyfrowego \\ - praktyki i perspektywy
}

DOI: $10.47050 / 65591777.116-144$

Janice Richardson

Internet zmienił oblicze społeczeństwa oraz sposób uczenia się i wchodzenia w interakcje z innymi. W całym okresie przemian - od początku istnienia tego medium aż do współczesności, w której społeczności z łatwością przekraczają granice między światem wirtualnym a rzeczywistym - bezpieczeństwo miało duże znaczenie. Współczesne społeczeństwa różnią się od wcześniejszych, a demokracje stają przed wieloma wyzwaniami. Wiele systemów edukacji nie zauważa jednak tych problemów, a kwestia bezpieczeństwa w sieci w najlepszym razie jest zaś jedynie dodatkiem do programu nauczania. W artykule zwrócono uwagę na kilka kluczowych zagadnień związanych z korzystaniem przez dzieci z internetu, porównując podejście do bezpieczeństwa w sieci z obywatelstwem cyfrowym. Przeanalizowano kompetencje, jakie powinni posiadać młodzi ludzie, aby skutecznie radzić sobie $z$ wyzwaniami związanymi $z$ technologiami cyfrowymi, a także niektóre modele zaproponowane przez organizacje międzynarodowe w celu zaspokojenia pojawiających się potrzeb.

\section{Słowa kluczowe:}

\section{technologia cyfrowa}

\section{obywatelstwo}

kompetencje

edukacja 


\section{From internet safety to digital citizenship \\ - practices and perspectives}

DOI: $10.47050 / 65591777.116-144$

Janice Richardson

Internet has transformed the face of society, and how people learn and interact within it. During the transition period from the early days of internet to today's almost seamless online-offline society, internet safety has played a crucial role for citizens of all ages. But today the face of society has changed, democracies are challenged, yet education systems tend to churn out more of the same, with internet safety at best no more than an add-on to the curriculum. The chapter highlights some of the key turning points in child online safety and compares internet safety approaches to digital citizenship, and the role of the family, NGOs and industry to that of schools. It examines the competences young people need to successfully cope with digital-related challenges, and some of the models proposed by international organisations to address emerging needs.

\section{Keywords:}

digital technology

citizenship

competences

education

internet safety 


\section{Wstęp}

Młodzi ludzie są zanurzeni w środowisku dużych zbiorów danych i nadmiaru informacji, a także w kulturze selfie. Ich życie towarzyskie rozgrywa się przez większość czasu w ogromnym wirtualnym świecie, w którym - chcąc być zauważeni - muszą pokazać, że są niezwykli, najmądrzejsi i najlepsi... lub najgorsi. Świat stał się globalną wioską - ze szkodą dla społeczności lokalnych, a wielu z nas zwraca więcej uwagi na telefon komórkowy niż na rodzinę i przyjaciół siedzących tuż obok. Sztukę dziennikarstwa zastąpił świat aspirujących reporterów i wolnych strzelców, którzy koncentrują się tylko na najbardziej spektakularnych tematach, ponieważ w przeciwnym razie ich artykuły nie zostaną opublikowane, a oni nie otrzymają wynagrodzenia. W dzisiejszych czasach dla wielu młodych ludzi głównym źródłem „informacji" są filmy na YouTubie kręcone przez ich rówieśników, szczególnie te poświęcone wrażliwym tematom, takim jak randki, seksualność czy makijaż. Pojawia się pytanie, jaki odsetek "guru" z YouTube'a ma na celu przekazanie rzetelnych informacji, a jaki rozpowszechnia porady zgodne $z$ interesami reklamodawców chętnych do korzystania $z$ tego potężnego kanału, żeby dotrzeć do pokolenia, które unika tradycyjnych mediów?

Krótko mówiąc, internet nieustannie oddziałuje na edukatorów i ekspertów do spraw bezpieczeństwa, którzy przez ostatnie dwie dekady głównie starali się - bez większych sukcesów - dotrzymać kroku temu narzędziu. Zaczynamy wreszcie akceptować fakt, że reagowanie na konkretne wyzwania związane z globalną siecią to syzyfowa praca, a organizacje działające na rzecz praw człowieka, takie jak Rada Europy i UNESCO, opracowują zupełnie nowe plany, ponieważ muszą całkowicie zmienić swoje podejście.

\section{Krótka historia bezpieczeństwa w internecie}

W dziejach internetu, obejmujących już kilkadziesiąt lat, można wyróżnić kilka interesujących etapów, ważnych z punktu widzenia nie tylko użytkowników, ale przede wszystkim rodziców, edukatorów i specjalistów do spraw bezpieczeństwa. Do końca lat dziewięćdziesiątych XX stulecia tylko nieliczne uprzywilejowane osoby mogły zastąpić powolne łącza modemowe szerokopasmowym dostępem do internetu w domu. Niemniej jednak edukatorzy już wtedy zastanawiali się, jak te potężne narzędzia informacyjne i komunikacyjne można wykorzystać 
w klasie, aby dać wszystkim uczniom nowe możliwości edukacyjne. Również dzieci i młodzież szybko dostrzegli możliwości, jakie daje internet. Mimo niedogodności związanych z dostępem wdzwanianym (dial-up) bardzo szybko przeglądarki takie jak Mosaic (1993), Netscape Navigator (1994) i Microsoft Explorer (1995) zmieniły surfowanie po internecie w pełną przygód rozrywkę.

Chociaż do 2000 r. nie więcej niż 5\% ludności świata postawiło pierwsze kroki w internecie ${ }^{1}$, w niektórych krajach Europy rozwój przebiegał w znacznie szybszym tempie. Na przykład w Wielkiej Brytanii badanie przeprowadzone na przełomie XX i XXI w. pokazało, że 75\% dzieci w wieku 7-16 lat korzystało z internetu (wśród osób dorosłych odsetek ten wyniósł zaledwie 38\%), a 36\% gospodarstw domowych z dziećmi miało dostęp do internetu (Wigley, Clarke 2000).

W obliczu wzrastającej liczby dzieci i młodzieży mających dostęp do internetu zwiększały się obawy społeczne. W rezultacie Komisja Europejska przyjęła pierwszy plan działań w sprawie internetu, który obowiązywał w latach 1999-2002. Od tego czasu organ ten realizował dwu- lub trzyletnie inicjatywy, przekształcając początkowy plan działań w programy „Bezpieczniejszy Internet”, a następnie „Bezpieczniejszy Internet Plus", aż do czasu przyjęcia w 2012 r. Europejskiej strategii na rzecz lepszego internetu dla dzieci. Wraz z rozszerzeniem Unii Europejskiej zwiększał się zasięg programu - od 15 krajów w 2004 r., kiedy Komisja Europejska utworzyła Europejską Sieć Bezpiecznego Internetu (Insafe), obejmującą 28 państw członkowskich oraz Islandię, Norwegię i Rosję. W ten sposób Wspólnota Europejska mogła zapewnić wsparcie krajowym centrom bezpieczeństwa internetowego przez finansowanie i szkolenia oraz propagowanie wymiany narzędzi i dobrych praktyk.

W tym czasie odnotowano wykładniczy wzrost wyzwań związanych z globalną siecią. Początkowo w zakresie bezpieczeństwa skoncentrowano się na ochronie dzieci przed szkodliwymi i nielegalnymi treściami, ponieważ szybko przybywały publicznie dostępne strony internetowe. W 2001 r. liczba zarejestrowanych nazw domen internetowych - dająca przybliżony obraz liczby istniejących stron internetowych - wynosiła 10 milionów, a na początku 2002 r. - już 20 milionów. Granicę miliarda stron osiągnięto we wrześniu 2014 r., obecnie jest ich już około 
1,7 miliarda (choć nie wszystkie są aktywne) ${ }^{2}$. Zbudowanie strony internetowej przekraczało techniczne kompetencje większości dzieci i młodzieży. Dla nich nowym, ekscytującym sposobem na poszerzenie kręgu odbiorców i wyrażanie opinii na forum publicznym stały się blogi. Dziś mogą być one postrzegane jako rozwiązania poprzedzające powstanie serwisów społecznościowych. Aby opisać ten bardziej otwarty, społecznościowy internet, ukuto termin „sieć 2.0".

\section{Od mediów społecznościowych do selfie, fake news i nie tylko...}

Wraz z uruchomieniem serwisu Myspace w 2003 r. i - niedługo później - krajowych platform mediów społecznościowych, takich jak Bebo w Wielkiej Brytanii czy Hyves w Holandii, grupy odpowiedzialne za podnoszenie świadomości w zakresie bezpieczeństwa w internecie szybko zwróciły uwagę na niepożądane i szkodliwe interakcje w sieci, dodając do problemu związanego z treściami kolejny, dotyczący kontaktowania się. Powstały w 2004 r. Facebook oraz uruchomiony w 2006 r. Twitter przysporzyły rodzicom kolejnych zmartwień, szybko stając się obiektem zainteresowania organizacji zajmujących się bezpieczeństwem w internecie. Mniej więcej w tym samym czasie YouTube (2005) zaoferował młodym ludziom zupełnie nowy sposób komunikowania się i dzielenia się treściami w skali globalnej, ponieważ graficzny charakter treści zniwelował problem różnic językowych. Wkrótce powstały Flickr, Tumblr i wiele innych podobnych narzędzi, które wypełniły nisze w mediach społecznościowych i jeszcze bardziej zwiększyły zakres wyzwań dla edukatorów oraz rodzin. Coraz większe znaczenie w programie na rzecz bezpieczniejszego internetu nadano zagadnieniu praw autorskich i niezamierzonego udostępniania danych osobowych.

Wprowadzenie na rynek iPhone'a w 2007 r. dało dzieciom duży zakres wolności i stało się ogromnym wyłomem w starannie opracowanych politykach bezpieczeństwa obowiązujących w rodzinach i szkołach. Kontrola rodzicielska i filtry już wcześniej nie były w pełni wykorzystywane, zwłaszcza w krajach nieanglojęzycznych, gdzie oferta tego rodzaju rozwiązań była ograniczona i słabo dostosowana do 
potrzeb. Z dnia na dzień zabezpieczenia znów stały się bezużyteczne, ponieważ dzieci mogły przez cały dzień korzystać z internetu w dowolnym miejscu. Do 2008 r. sprzedano 1,4 miliona iPhone'ów, a na rynku pojawiła się szeroka oferta wydajnych, niedrogich smartfonów innych firm. Zaledwie rok później na rynek trafiło już ponad 50 tysięcy aplikacji, co spowodowało powstanie nowych kwestii problematycznych, dotyczących między innymi podawania danych osobowych i uzyskiwania zgody rodziców. Łatwe w obsłudze i dostępne w większości telefonów aparaty i kamery otworzyły drogę nowym wyzwaniom związanym z prywatnością i bezpieczeństwem. W 2013 r. „selfie” zostało wybrane słowem roku słownika Oxford English Dictionary (Backer 2017).

Począwszy od 2008 lub 2009 r., gdy telefony komórkowe i tablety upowszechniły się w wielu rodzinach, pojawiły się nowe wyzwania społeczne - okazało się, że dzieci stawiają pierwsze kroki w internecie, zanim jeszcze nauczą się chodzić lub mówić. W okresie, gdy powinny przyswajać sobie wartości i postawy obserwowane w domu rodzinnym, są rzucane w środek globalnego świata - czyli tam, gdzie rodzice i wychowawcy mają trudności z kontrolowaniem każdego kontaktu z ludźmi i treściami. Wszechobecny dostęp do technologii we wczesnym dzieciństwie jest ponadto łączony z opóźnieniami w rozwoju koncentracji, małej motoryki i sprawności ruchowej, umiejętności mówienia i socjalizacji, jak również ze wzrostem zachowań agresywnych i aspołecznych, a także z otyłością i przemęczeniem (Aiken 2016).

Jednym ze skutków wtórnych korzystania z technologii przez bardzo małe dzieci było zakończenie trwającej ponad dekadę debaty na temat tego, kto powinien być odpowiedzialny za nauczanie o bezpieczeństwie w internecie - rodzina czy szkoła. Zjawisko to prowadzi również do pogłębienia podziałów społecznych. Dotyczy to dzieci w rodzinach ze wszystkich warstw społeczno-zawodowych i-jak zawsze w podobnych sytuacjach - niektórzy rodzice lepiej sobie radzą z tym wyzwaniem niż inni. Badanie przeprowadzone niedawno w Stanach Zjednoczonych na grupie 350 dzieci w wieku od sześciu miesięcy do czterech lat, wychowujących się w społecznościach o niskich dochodach lub pochodzących z mniejszości etnicznych pokazało, że $97 \%$ z nich miało kontakt z internetem. Wykazało ono także, że $20 \%$ rocznych dzieci ma swój tablet, $28 \%$ dwulatków potrafi obsługiwać urządzenia mobilne bez pomocy dorosłych, a 75\% czterolatków ma własne urządzenie przenośne (Kabali i in. 2015). 
W 2016 r. zwrócono uwagę na kwestie fałszywych wiadomości (fake news), profilowania, manipulowania mediami i nadmierną przemoc. Lista jest długa i z każdym rokiem coraz dłuższa. Tak poważne wyzwania społeczne wykraczają poza zakres bezpieczeństwa w internecie, ponieważ sięgają głęboko w tkankę społeczną.

Ilustracja 1. Dwie dekady wyzwań w zakresie bezpieczeństwa w internecie i reakcja Europy

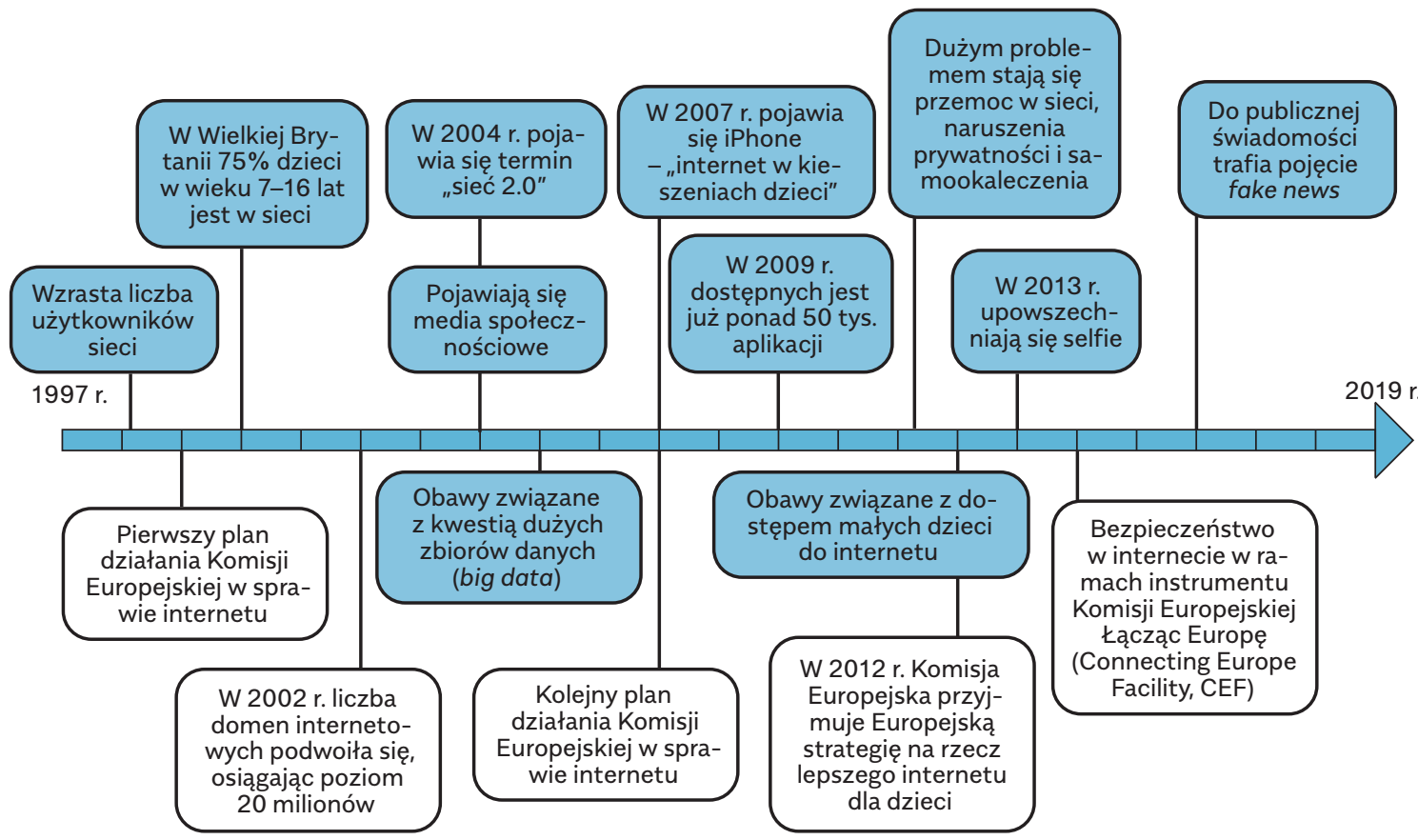

\section{Dzień Bezpiecznego Internetu - stały punkt na szybko zmieniającej się mapie bezpieczeństwa}

Opracowana w Luksemburgu w 2003 r. koncepcja Dnia Bezpiecznego Internetu została po raz pierwszy wprowadzona w życie w ramach realizowanego z udziałem 14 państw członkowskich Unii Europejskiej i koordynowanego przez Hiszpanię projektu pod nazwą "Safeborders". Zakładał on, że przez jeden dzień w roku społeczeństwa i media będą się zastanawiać nad postępem rozwoju internetu i jego wpływem na życie Europejczyków. Pierwszy Dzień Bezpiecznego Internetu odbył się 6 lutego 2004 r. i obchodzony był przez dzieci i rodziny w 12 pań- 
stwach europejskich (Dania, Niemcy, Grecja, Islandia, Irlandia, Włochy, Luksemburg, Holandia, Norwegia, Hiszpania, Szwecja, Wielka Brytania) oraz w Australii3.

Obecnie Dzień Bezpiecznego Internetu jest obchodzony co roku w ponad 140 krajach na świecie i bierze w nim udział ponad 50 milionów osób. Jest on również szeroko propagowany w mediach społecznościowych - w 2016 r. odnotowano ponad miliard tweetów na ten temat. W niektórych krajach obchody trwają przez cały tydzień, a w innych, na przykład w Rosji, nawet miesiąc. W ich ramach firmy z branży wprowadzają na rynek nowe produkty, a instytucje europejskie ${ }^{4}$ i międzynarodowe 5 informują opinię publiczną o nowych inicjatywach służących ochronie dzieci i ich praw w internecie.

Dlaczego Dzień Bezpiecznego Internetu jest ważny? Dlaczego jest tak szeroko obchodzony? Opinia publiczna zazwyczaj szybko traci zainteresowanie kampaniami informacyjnymi, ale sytuacja ta nie dotyczy Dnia Bezpiecznego Internetu. Co roku obchody koncentrują się na innym zagadnieniu, stanowiąc pewnego rodzaju punkt zwrotny w świadomości społecznej. Co roku sieć Insafe, działająca pod patronatem Komisji Europejskiej, opracowuje hasło przewodnie obowiązujące na całym świecie, które odzwierciedla najważniejsze kwestie związane z korzystaniem z internetu przez dzieci i dorosłych. Kolejną przyczyną sukcesu Dnia Bezpiecznego Internetu jest to, że został zaprojektowany w taki sposób, że sieć jako medium sama staje się przekazem. Na przykład w 2005 r. zorganizowano blogathon (globalny blog poświęcony bezpieczeństwu w internecie), do którego poszczególne kraje kolejno się przyłączały, zgodnie ze strefami czasowymi na całym świecie. Od 2008 r. kluczowe wiadomości były przekazywane za pomocą klipów wideo, a obecnie media społecznościowe, w tym Facebook i Twitter, zostały włączone do platform kampanii. Zawsze był także trzeci element, który utrzymywał zainteresowanie Dniem Bezpiecznego Internetu - obchody skupiają się na prawach dziecka, a nie na restrykcjach

3 Unia Europejska obchodzi Dzień Bezpiecznego Internetu 6 lutego. Więcej informacji na stronie internetowej: bit.ly/2TZsJsT [dostęp: 20.03.2019].

4 Project activities: 7th Safer Internet Day. Więcej informacji na stronie internetowej: bit.ly/2UMuB5g [dostęp: 20.03.2019]. 
i ograniczeniach, na możliwościach, a nie zagrożeniach, na użytkownikach, a nie na narzędziach. W tak szybko się rozwijającym środowisku jak internet stałe punkty są ważnymi elementami, a Dzień Bezpiecznego Internetu zyskał uznanie i renomę.

\section{Internet - wierzcholek góry lodowej}

Internet jest dziś miejscem, w którym około połowa ludności świata spędza średnio ${ }^{6}$ niemal dwie godziny dziennie. Mając w 2018 r. dziennie 1,47 miliarda aktywnych użytkowników ${ }^{7}$, Facebook stał się przestrzenią o znacznie większej liczbie "mieszkańców" niż jakikolwiek kraj na ziemi.

Samo słowo „internet" ma dziś zupełnie inne znaczenie niż wtedy, gdy po raz pierwszy pojawił się termin „bezpieczeństwo w sieci". Nie zdajemy sobie $z$ tego sprawy, ale mamy w domach coraz więcej urządzeń przekazujących przez internet nasze dane w formie obrazów, tekstu i mowy, które są przechowywane na serwerach umieszczonych w nieznanych nam miejscach. Za pośrednictwem maskotek, które "słuchają" i „mówią", skończywszy zaś na elektronicznych nianiach, które stawiamy w sypialni naszego dziecka i podłączonych do sieci czarnych skrzynkach w naszych samochodach, przekazujemy różne dane organizacjom, które próbują kształtować nasze zwyczaje związane z przeglądaniem i zakupami lub szacować zakres ryzyka ubezpieczeniowego. Jeśli przyjmiemy założenie, że sztuczna inteligencja definiuje systemy komputerowe, które mogą wykonywać zadania zazwyczaj wymagające udziału ludzi (na przykład percepcji wzrokowej, rozpoznawania mowy, podejmowania decyzji i tłumaczenia na inne języki), to społeczeństwo jest zalewane sztuczną inteligencją, a internet nie jest niczym więcej, jak tylko wierzchołkiem ogromnej góry lodowej. Aby stawić czoła bardziej złożonym zagadnieniom, powinniśmy edukować dzieci i siebie samych bardziej holistycznie i całościowo.

Kiedy ponad dwie dekady temu ukuto termin "bezpieczeństwo w internecie", główne wyzwania dotyczyły, jak już wspomniano wcześniej, ochrony dzieci przed szkodliwymi i nielegalnymi treściami. Inną ważną kwestią było zapobieżenie sytuacji, w której internet stałby się narzędziem rozpowszechniania treści dotyczących wykorzystywania 
seksualnego dzieci. W związku z tym pod koniec lat dziewięćdziesiątych XX stulecia powstała sieć INHOPE. Od tego czasu liczba wyzwań rośnie w tempie wykładniczym wraz z pojawieniem się portali społecznościowych, coraz mniejszych i bardziej wydajnych urządzeń mobilnych oraz stale zwiększającej się przepustowości, co wymaga skupienia się na zachowaniach i możliwościach. Z myślą o tym stworzono sieć Komisji Europejskiej „Safer Internet Network” (Insafe), która umożliwia propagowanie wiedzy i dzielenie się doświadczeniami przez państwa członkowskie, a tym samym ograniczenie kosztownego powielania tych samych działań w różnych krajach. Do 2012 r. sieć służyła również jako pewnego rodzaju system ostrzegawczy dla państw, w których wdrażanie nowych technologii przebiegało wolniej niż w innych.

W ostatniej dekadzie ważną rolę w zakresie bezpieczeństwa odegrały infolinie, udzielając specjalistycznych porad psychologicznych młodym ludziom, a także ich rodzicom i nauczycielom. Były one również pomocne w rozpoznawaniu pojawiających się tendencji i rosnących obaw społecznych. Podczas gdy wcześniej na infolinie dzwoniono, aby uzyskać pomoc w rozwiązaniu problemów technicznych lub w usuwaniu treści, dziś ich pracownicy mają do czynienia z takimi kwestiami jak: utrata dobrego samopoczucia lub z problemy behawioralne. Coraz więcej zgłoszeń napływa od zdezorientowanej młodzieży (blisko 70\%, jak wynika z danych statystycznych Insafe za drugi kwartał 2018 r.), podczas gdy kilka lat temu kontaktowali się głównie rodzice, nauczyciele i opiekunowie. llustracja 2 przedstawia kategorie spraw zarejestrowanych przez infolinię Insafe we wspomnianym okresie. 
Ilustracja 2. Tematy rozmów na infolinii Insafe (stan na drugi kwartał 2018 r. $^{8}$ )

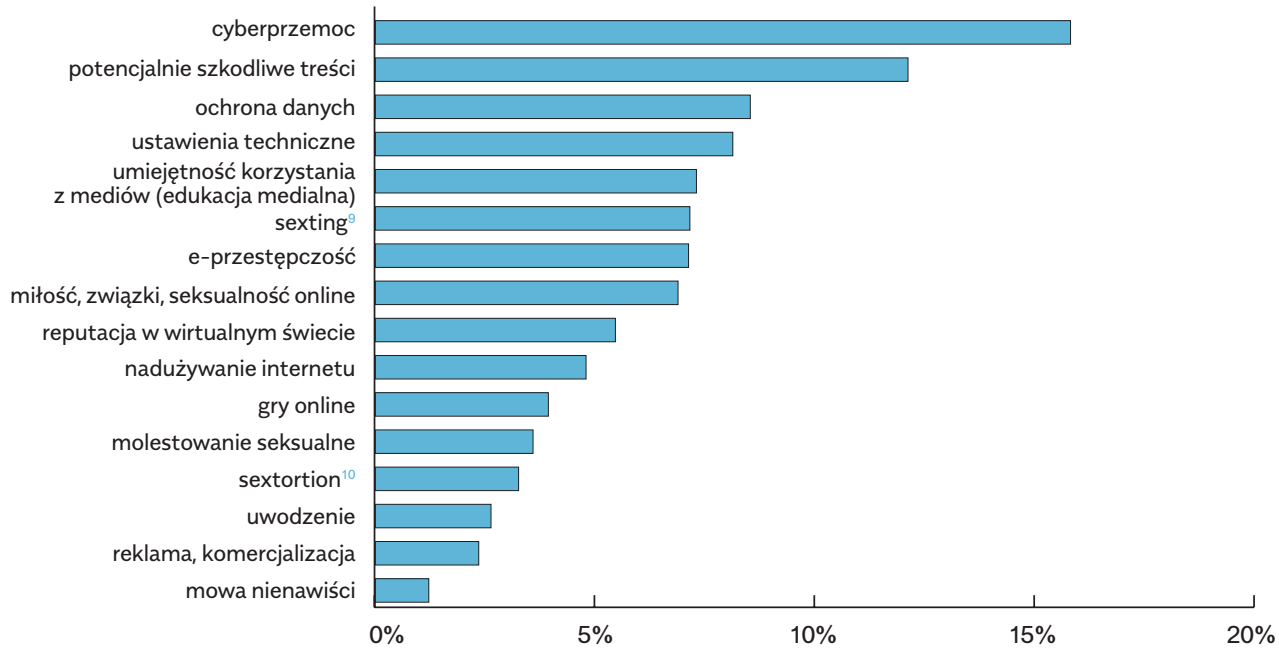

Biorąc pod uwagę, że ponad jedną czwartą wszystkich zgłoszeń na infolinii stanowią tematy związane z cyberprzemocą i potencjalnie szkodliwymi treściami, można uznać, że młodzi ludzie szukają pomocy w sytuacji wystąpienia symptomów, które oznaczają głębszy problem wynikający z deregulacji związanej z technologiami cyfrowymi. W ubiegłych latach obawy młodych ludzi dotyczące danych osobowych i prywatności zmniejszyły się, co wskazuje, że prawdopodobnie stali się oni bardziej świadomi wartości swoich danych osobowych oraz znaczenia tożsamości cyfrowej i śladów cyfrowych, w związku z czym są w stanie sami zająć się tymi zagadnieniami.

Jednym z elementów pracy operatorów infolinii jest rozmowa z kolegami z innych krajów i dzielenie się danymi na temat pojawiających się problemów w celu stworzenia możliwie najbardziej użytecznej, wspólnej bazy wiedzy. Pozwala to na lepsze szkolenie zespołów krajowych i przygotowanie pracowników infolinii na wyzwania, zgodnie z zasadą: „wcześniej ostrzeżony, lepiej przygotowany". Infolinie są również helplines.betterinternetforkids.eu [dostęp: 20.03.2019]. 
w stanie wykorzystać informacje i wiedzę czerpaną z bezpośrednich kontaktów z użytkownikami, do uzgadniania działań naprawczych z mediami społecznościowymi i dostawcami narzędzi. Branża szybko uznała to za okazję do pełniejszego poznania potrzeb użytkowników i kształtowania narzędzi, jak również do ochrony dzieci i poszanowania ich praw. Większość dużych dostawców mediów społecznościowych utworzyła rady konsultacyjne i stworzyła możliwości spotkań nie tylko za pośrednictwem infolinii, lecz również z ekspertami i edukatorami zajmującymi się dobrostanem dzieci.

Kolejną tendencją, która zdaje się wskazywać na to, że internet jest tylko wierzchołkiem góry lodowej, jest pozornie większa odpowiedzialność, którą młodzi ludzie wykazują, wspierając się wzajemnie nie tylko w kwestiach związanych z siecią, ale także w innych obszarach życia. Dla wielu z nich internet stał się platformą, na której mogą się spotykać i wypowiadać się na różne tematy, począwszy od kultury, różnorodności i ochrony środowiska, skończywszy zaś na kwestiach zakazu posiadania broni i obalania partii politycznych, jak to było podczas „arabskiej wiosny". Młodzi wykorzystują również nowe możliwości, uruchamiając własne firmy lub tworząc aplikacje i narzędzia (na przykład filmy na YouTubie), które kształtują świat zarówno cyfrowy, jak i realny.

Od 2009 r. swoistym organem doradczym stały się krajowe panele młodzieżowe, utworzone w ramach Sieci Bezpieczniejszego Internetu Komisji Europejskiej. W skład takiego panelu wchodzi po kilku młodych ludzi z każdego państwa skupionego w tej sieci. Uczestnicy co roku spotykają się na kilka dni, aby przedstawić swoje poglądy na temat tego, w jaki sposób sprawić, by internet, a także - bardziej ogólnie - Europa i świat, stały się lepszym miejscem. W Dniu Bezpiecznego Internetu w 2018 r. powołano też stałą Radę młodzieży do spraw bezpiecznego internetu (Council for Digital Good, CDG), w której skład wchodzi 15 młodych ludzi w wieku od 13 do 20 lat z siedmiu krajów europejskich, którzy będą współpracować z edukatorami, politykami i organizacjami międzynarodowymi, aby włączyć głos młodzieży w debatę polityczną. Podobne rady istnieją w Stanach Zjednoczonych, na Bliskim Wschodzie i w Afryce. Dzięki takim i podobnym strukturom na całym świecie twórcy regulacji zaczynają dostrzegać i uwzględniać życzenia oraz potrzeby młodych ludzi, choć, niestety, w wielu wypadkach tylko przedstawiciele bogatszych, wielojęzycznych środowisk mogą w ten sposób dzielić się 
swoimi opiniami. Choć internet jest punktem wyjścia i platformą komunikacyjną, jego wpływ wykracza daleko poza sferę wirtualną.

Omówione tendencje pokazują, że rzeczywistość cyfrowa stale się zmienia i rozwija. Wskazują również, że istnieje pilna potrzeba, aby szkoły, rodziny i społeczności uwzględniały lepiej dostosowane koncepcje zdobywania umiejętności i wiedzy oraz zagadnienia obywatelstwa w edukacji swoich dzieci.

\section{Obywatelstwo w cyfrowym świecie bez granic}

Ponieważ internet wkracza w każdy obszar naszego życia, a granice między światem wirtualnym i realnym oraz między poziomem lokalnym i globalnym coraz bardziej się zacierają, niewidoczne fragmenty wspomnianej góry lodowej wpływają na społeczeństwo w sposób niemożliwy do przewidzenia. Jednym z przykładów jest obniżenie wiary w demokrację i wzrost postaw nacjonalistycznych. Zwrócono na to uwagę w przeprowadzonym niedawno badaniu ${ }^{11}$ na temat obywatelstwa, przejawem tego zjawiska jest również niski poziom frekwencji w wyborach krajowych. W 1996 r. Jacques Delors, były przewodniczący Komisji Europejskiej, wspominał o niektórych głębokich podziałach społecznych, jakich się spodziewał: „[...] jak możemy nauczyć się wspólnego życia w «globalnej wiosce», jeśli nie potrafimy żyć razem w społecznościach, do których naturalnie należymy - w narodzie, regionie, mieście, wiosce, dzielnicy?" (Delors i in. 1996).

Według Jacques'a Delorsa społeczeństwo może odnieść sukces tylko wtedy, gdy każda osoba wchodząca w jego skład wykazuje chęć, ma możliwości i czuje się na tyle zaangażowana, żeby uczestniczyć w życiu publicznym i mieć wkład w jego budowanie. Wymaga to również poczucia odpowiedzialności, podstawowego elementu w społeczeństwie w szybkim tempie zmierzającym w kierunku technologii typu blockchain. Postrzega się ją jako antidotum na brak przejrzystości i zaufania do posiadanych uprawnień. W ramach takiej, ogólnie rzecz ujmując, zdecentralizowanej, rozproszonej i otwartej technologii każdy człowiek staje się bezpośrednio lub pośrednio odpowiedzialny za zasadność i przejrzystość działań. Od wielu lat obserwujemy tego typu struktury w mediach społecznościowych, w których dostawcy tworzą 
platformę, ale użytkownicy wypełniają ją treścią, wchodzą w interakcje i uwierzytelniają zamieszczane materiały. Innym, bardziej złożonym przykładem są kryptowaluty.

Obecnie model typu blockchain znajduje zastosowanie w sferze publicznej, na przykład w opiece zdrowotnej. Warto zadać pytania: w jakiej sytuacji są obywatele, którzy nie mają podstawowych kompetencji, pozwalających świadomie reagować i uczestniczyć w tych procesach? Czy nadal są panami własnego życia?

\section{Bezpieczeństwo w internecie lub obywatelstwo cyfrowe - na czym polega różnica?}

Chociaż dawniej bezpieczeństwo w internecie wiązało się głównie z opracowywaniem zasad i przepisów mających na celu ochronę dzieci, to na szczęście dość szybko obszar ten się poszerzył. Obecnie obejmuje on również akcje edukacyjne dla młodych ludzi dotyczące bezpiecznego i odpowiedzialnego korzystania z technologii oraz unikania pułapek. Dziś koncepcją tą zajmuje się wielu partnerów, a dotyczy ona między innymi:

$\rightarrow$ narzędzi: filtry, timery, firewalle, oprogramowanie zabezpieczające,

$\rightarrow$ ludzi: od rodziców, opiekunów i wychowawców po samych użytkowników,

$\rightarrow$ zasobów wykorzystywanych przez zaangażowane osoby,

$\rightarrow$ wytycznych dla branży, dotyczących narzędzi i usług wykorzystywanych na platformach, często określanych jako „bezpieczeństwo w fazie projektowania",

$\rightarrow$ usług: infolinii wspierających użytkowników i służących im radą w wypadku wystąpienia problemów, a także uwzględniania wyciągniętych wniosków w zakresie bezpieczeństwa poprzez zwrócenie na nie uwagi osób odpowiedzialnych za podnoszenie świadomości i edukatorów.

Oczywiście zagadnienia bezpieczeństwa w internecie i obywatelstwa cyfrowego nakładają się na siebie w wielu obszarach. Podczas gdy bezpieczeństwo koncentruje się na ochronie dzieci i prognozowanych praktyk użytkowników, podejść i narzędzi, obywatelstwo cyfrowe jest procesem oddolnym, który obejmuje szeroki zakres „kompetencji życiowych" i rozpoczyna się w momencie narodzin dziecka. Koncentruje się na wartościach, postawach, umiejętnościach i wiedzy oraz na krytycz- 
nej analizie, czyli elementach, które jednostki wnoszą w każdy aspekt swojego życia, zarówno w internecie, jak i poza nim. „Obywatelstwo cyfrowe" kształtuje to, kim jesteśmy, sposób, w jaki się uczymy, działamy i komunikujemy z najbliższym otoczeniem lub ze społecznością, a także w szerszym świecie. Może być interpretowane jako rama albo filtr, który wzmacnia sygnały odbierane za pośrednictwem wszystkich pięciu zmysłów. Wpływa na zachowania ludzi w każdym miejscu i we wszystkich okolicznościach. Kompetentni obywatele cyfrowi to osoby, które:

$\rightarrow$ angażują się w życie społeczne i technologie cyfrowe, z których korzysta społeczeństwo,

$\rightarrow$ są aktywnymi członkami społeczności w których żyją, mającymi pozytywny i konstruktywny wkład w ich funkcjonowanie,

$\rightarrow$ uczą się przez całe życie, aby nadążać za zmianami zachodzącymi wokół nich.

W centrum obywatelstwa cyfrowego znajduje się edukacja - w domu, w społeczności, w szkole i wszędzie tam, gdzie spotykamy się z informacjami i innymi ludźmi.

\section{Rola rodziny, rola szkoły}

Mimo wysiłków Komisji Europejskiej (w ramach programu „Bezpieczniejszy Internet" oraz Europejskiej strategii na rzecz lepszego internetu dla dzieci), resortów edukacji w niektórych krajach oraz wielu podmiotów, w tym instytucji publicznych i organizacji pozarządowych, bezpieczeństwo w sieci nigdy nie zostało w pełni włączone do szkolnych programów nauczania. Od czasu, gdy internet stał się częścią życia dzieci, jesteśmy świadkami toczącej się walki między szkołą a rodziną o to, kto powinien odpowiadać za ochronę dzieci w tym zakresie. Spór ten trwa, wydaje się jednak, że organizacje pozarządowe i przedstawiciele branży postanowili przystąpić do działania. Pojawia się pytanie o to, dlaczego instytucje oświatowe i wyszkoleni pedagodzy zrzekają się odpowiedzialności w kwestii, od której może zależeć przyszłość społeczeństwa. Jest wiele przyczyn, dla których szkoły tak wolno podejmują to wyzwanie. Pierwsza z nich jest związana z infrastrukturą. W placówkach edukacyjnych w całej Europie występują duże różnice w poziomie dostępności technologii cyfrowych. Dotyczy to zwłaszcza szkół podstawowych, w których nauczyciele powinni pomagać dzieciom 
w rozwijaniu umiejętności i praktyk, jakie będą pogłębiać podczas samodzielnego korzystania z internetu. Obecnie większość dzieci, przynajmniej w Europie, ma własne komputery lub smartfony, a niektóre kraje, na przykład Austria, stosują politykę „przynieś własne urządzenie”, aby wypełnić tę lukę. Jednak wyzwania związane z bezpieczeństwem w internecie, widoczne różnice społeczne wynikające z klasy urządzeń, które dzieci mogą przynosić do szkół, oraz obawy nauczycieli związane z zakłócaniem przebiegu lekcji okazały się bardzo trudne do pokonania. W niektórych regionach przedstawiciele branży lub rząd dostarczają do szkół odpowiedni sprzęt, ale jest to działanie kosztowne, zwykle jednorazowe i w dłuższej perspektywie czasowej nietrwałe, aby można je było traktować jako wystarczające, przynajmniej w wypadku publicznych placówek oświatowych dla młodszych dzieci.

Drugim czynnikiem jest program nauczania. Jak dotąd uczenie się o technologii cyfrowej i nauczanie za jej pomocą nie było traktowane jako obowiązkowe na poziomie szkolnictwa podstawowego. Kiedy przedmiot ten staje się częścią programu nauczania w szkole średniej, nacisk kładzie się głównie na obszar STEM (nauki ścisłe, technologię, inżynierię i matematykę), a nie na aspekty związane z działaniami prewencyjnymi lub obywatelskimi. Do czasu, gdy technologia cyfrowa zostanie w pełni uwzględniona w programie nauczania, a resorty edukacji określą jednoznaczne definicje oraz wytyczne w zakresie wymogów, osiągnięć i ewaluacji, wydaje się, że tylko najbardziej przedsiębiorczy nauczyciele są gotowi zmierzyć się z tematyką bezpieczeństwa w internecie. Istnieje wiele bardzo ciekawych programów dla nauczycieli (jednym z nich jest eTwinning), ale liczba korzystających z nich szkół i nauczycieli jest niewielka.

Trzeci czynnik, który ma wpływ na to, że zagadnienia bezpieczeństwa w internecie nie są odpowiednio realizowane w szkołach, dotyczy kwestii szkoleń i zasobów dydaktycznych zatwierdzonych na poziomach rządowych. Nie jest zaskoczeniem, że nauczyciele to także aktywni użytkownicy cyfrowych produktów i usług, którzy wykorzystują je w podróży, podczas obsługi bankowości elektronicznej lub robiąc zakupy. Zazwyczaj są oni jednak dość sceptycznie nastawieni do stosowania niesprawdzonych strategii pedagogicznych w obszarze, który może mieć tak daleko idące skutki (a takim jest wpływanie na zachowania dzieci w internecie). Dlatego szkoły w wielu krajach zdecydowały się na stosowanie polityki ograniczenia korzystania z komputerów i sieci 
do określonych zajęć z klasie, wyraźnie zatwierdzonych programem nauczania, i zabraniają korzystania z telefonów komórkowych, zamiast rozpocząć zajęcia dotyczące bezpieczeństwa w internecie. Dostępne są kursy MOOC, szkolenia online w formie webinariów i sesje szkoleniowe, ale do czasu, aż zagadnienia związane z siecią staną się integralną częścią kształcenia nauczycieli lub obowiązkowego doskonalenia zawodowego, dla większości pedagogów problemy te będą znajdować się poza obszarem ich zainteresowania. Pracownicy szkół mają tendencję do traktowania budynków instytucji jako granicy ich odpowiedzialności. Za to, co się dzieje w domu, odpowiadają rodzice, to zaś, co się dzieje między szkołą a domem, pozostaje w zawieszeniu, do czasu, aż sytuacja stanie się tak zła, że nie da się uniknąć podjęcia kroków przez którąś ze stron.

Gdzieś między domem a szkołą dostępne są usługi infolinii, które, jak wspomniano wcześniej, w wielu państwach Unii Europejskiej są dofinansowane przez Komisję Europejską. Młodzi ludzie mogą tutaj telefonicznie, mailowo lub za pośrednictwem czatu uzyskać porady od psychologów i specjalistów związane z wątpliwościami dotyczącymi użytkowania internetu. Jednakże infolinie mają za zadanie udzielać wskazówek i wsparcia, a nie edukować. Statystyki wskazują, że nauczyciele i rodzice korzystają z ich usług równie często, jeśli nie częściej, niż dzieci i młodzież. Niemniej jednak infolinie mogłyby stanowić wartościowe źródło informacji dla edukatorów, ponieważ gromadzą one dane na temat pojawiających się tendencji, a to z kolei umożliwia identyfikowanie wrażliwych obszarów, które w przeciwnym razie nie zostałyby wykryte. Jednak aby infolinie mogły odgrywać taką rolę, musiałyby uzyskać więcej funduszy i należałoby wprowadzić odpowiednie mechanizmy współpracy między nimi a szkołami. Co więcej, bezpieczeństwo w sieci musiałoby być uwzględnione w zakresie ich zadań.

Obywatelstwo cyfrowe łączy rolę rodziny i szkoły, zasadza się bowiem na szerszych, dokładniej zdefiniowanych kompetencjach. Rozwijanie wielu z nich trzeba rozpocząć, zanim dzieci pójdą do szkoły. Infrastruktura staje się zbędna, ponieważ kompetencje obywatelskie są takie same zarówno w sieci, jak i poza nią. Programy nauczania w szkołach w całej Unii Europejskiej już teraz powinny uwzględniać edukację moralną i obywatelską, choć na ogół przeznacza się na te przedmioty nie więcej niż 6-8\% łącznego wymiaru godzin nauczania na poziomie 
podstawowym lub średnim ${ }^{12}$. Obywatelstwo cyfrowe integruje i może zastąpić oba przedmioty. Nie można więc wykluczyć, że znajdzie się w szkołach, jeśli zostaną zapewnione niezbędne szkolenia i zasoby dla nauczycieli.

\section{Technologia cyfrowa, rozwój społeczno-emocjonalny i zachowanie}

W ostatnich latach przeprowadzono interesujące badania nad sposobem, w jaki technologia cyfrowa wpływa na nasze życie, naukę i interakcje. W książce The Shallows Nicholas Carr (2010) twierdzi, że nasze myśli, procesy myślowe, a nawet mózg ulegają zmianom pod wpływem technologii. Przedstawia wyniki badań empirycznych, które wykazują potencjalny wpływ częstego korzystania z urządzeń cyfrowych na młody mózg, którego boczny płat staje się nadmiernie rozwinięty z powodu ekspozycji na szybko poruszające się obrazy i dźwięki. To ma, jak się wydaje, szkodliwy wpływ na inne obszary mózgu związane z myśleniem, metapoznaniem oraz umiejętnościami prowadzenia analizy i myślenia krytycznego.

Kolejny badacz, Roman Krznaric (2014), koncentruje się na znaczeniu empatii jako podstawie praw człowieka i sprawiedliwości społecznej. Autor przedstawia czynniki, które mogą wyjaśnić, co wpływa na młodych ludzi oraz ich interakcje w świecie wirtualnym i rzeczywistym.

Również nauczyciele przedszkoli i szkół podstawowych wyrażają obawy na temat częstego korzystania z technologii w zbyt młodym wieku (Aiken 2016). Uważają, że może to powodować pominięcie ważnych etapów rozwoju i osłabienie kształtowania mowy. Czas koncentracji ulega skróceniu, zmniejsza się również kreatywność, gdy dzieci i młodzież spędzają więcej wysiłku na konsumowaniu, a nie na tworzeniu treści. Wyniki badania przeprowadzonego w 2016 r. wśród dzieci w wieku 11-14 lat w ramach projektu ENABLE, mającego na celu przeciwdziałanie nękaniu13, wskazują, że prawdopodobnie z powodu zmniejszonego czasu bezpośrednich interakcji społecznych 40-57\% przedstawicieli badanej grupy miało trudności z definiowaniem ne[dostęp: 25.03.2019]. 
gatywnych emocji. Około $25 \%$ nastolatków przyznało, że nie umie ani nie ma ochoty pomagać innym. Przedziały procentowe były mocno zróżnicowane w pięciu państwach członkowskich Unii Europejskiej zaangażowanych w realizację projektu, co wymaga dalszych analiz, aby zrozumieć czynniki mające wpływ na takie wyniki.

Główni dostawcy mediów społecznościowych są świadomi zmian społecznych i behawioralnych związanych z oferowanymi przez nich platformami. Oczywiście, realizując modele biznesowe, regularnie współpracują z ekspertami w dziedzinie bezpieczeństwa, instytucjami i rządami w ramach programów samoregulacji i wspólnych unormowań, próbując zapewnić, że media społecznościowe mają pozytywny wpływ na młodych ludzi. W ramach takich inicjatyw stworzyły one m.in. mechanizmy szybkiego usuwania ze stron internetowych treści związanych z ekstremizmami i wykorzystywaniem seksualnym dzieci, usprawniły procedury raportowania, zaostrzyły ustawienia dotyczące prywatności oraz zapewniły narzędzia ułatwiające użytkownikom kontrolowanie wizerunku w internecie. Facebook i Google współpracowały np. z czołowymi przedstawicielami świata nauki i ekspertami przy tworzeniu cyfrowych bibliotek zawierających scenariusze lekcji i zasoby. Twitter opracował niedawno "wskaźniki bezpieczeństwa”, które mają służyć jako swoisty barometr prawidłowości interakcji zachodzących na ich platformie. Wskaźniki obejmują poziom różnorodności zagadnień, na które użytkownicy są skłonni wypowiadać się na platformie, a także poziom otwartości, jaki wykazują, gdy stają w obliczu innych niż wyznawane przez nich wartości. Twitter ogłosił niedawno konkurs dla badaczy chętnych do podjęcia dalszych analiz.

Tego rodzaju inicjatywy wskazują na to, że zarówno przedstawiciele przemysłu, jak i naukowcy są świadomi głębokich zmian zachodzących w społeczeństwie i reagują na nie. Zdają sobie sprawę, że zapewnienie odpowiedniej ochrony użytkownikom i bezpiecznej, otwartej przestrzeni, w ramach której mogą oni korzystać ze swoich praw, wymaga czegoś więcej niż tylko ustalenia zasad i przekazywania porad. Przekonaliśmy się już, w jakim stopniu media społecznościowe mogą wzmocnić pozycję młodych ludzi oraz umożliwić im swobodne wyrażanie opinii, spotykanie się i pracę z rówieśnikami, a także wypowiadanie się w sprawach dotyczących ich życia. Są to niezbywalne prawa dziecka zapisane w Konwencji Narodów Zjednoczonych o prawach 
dziecka (UNCRC) ${ }^{14}$, a dzisiejsze młode pokolenie ma bezprecedensowe możliwości ich egzekwowania za pomocą środków cyfrowych, które pozwalają przezwyciężyć przeszkody czasu, odległości i ograniczeń fizycznych. Ostatnio przyjęte ogólne rozporządzenie o ochronie danych osobowych (RODO) ${ }^{15}$, wdrażane od maja 2018 r., przyczynia się budowania przez Unię Europejską ram, które wzmacniają w tym zakresie prawa obywateli w każdym wieku.

Technologia cyfrowa zakłóciła dawne porządki społeczne w takim stopniu, że tylko dogłębna zmiana podejścia do edukacji może przynieść pożądane skutki. Troska o bezpieczeństwo w internecie była dość skutecznym tymczasowym rozwiązaniem na potrzeby okresu przejściowego, który właśnie się kończy. Obecnie, w dobie sztucznej inteligencji i uczenia się maszyn, musimy jednak szukać nowych metod, aby przygotować obywateli na przyszłość opartą na technologii cyfrowej. Obywatelstwo cyfrowe może przyczynić się do rozwiązania tego problemu.

\section{Korzenie cyfrowej edukacji obywatelskiej}

We wspomnianej już publikacji Jacques Delors podkreśla ogromne znaczenie edukacji, która umożliwia dzieciom osiąganie ich pełnego potencjału jako obywateli, a tym samym przyczynia się do ich dobrostanu i zrównoważonego rozwoju otoczenia, w którym żyją. Autor ten utrzymuje, że edukacja jest jedynym rozwiązaniem i że musi zasadzać się na czterech filarach: uczyć się, aby wiedzieć, aby działać, aby być i żyć wspólnie. Instytucje kształcenia ustawicznego i osoby odpowiedzialne za tworzenie polityki w Europie, ale także na całym świecie, walczą o wprowadzenie zmian w edukacji, które pomogą osiągnąć te cele. W ostatnich kilkudziesięciu latach znajduje to odzwierciedlenie w obszarze zainteresowania instytucji takich jak OECD (Organizacja Współpracy Gospodarczej i Rozwoju) i badaniach PISA (Program międzynarodowej oceny umiejętności uczniów) ${ }^{16}$. Wyniki badania Internastronie internetowej: bit.ly/2JJh901 [dostęp: 20.03.2019]. jest dostępny na stronie internetowej: bit.ly/2vHVeNC [dostęp 20.03.2019]. 
tional Civic and Citizenship Education Study (ICCS), przeprowadzonego przez IEA (International Association for the Evaluation of Educational Achievement) w roku 2016, również, jak się wydaje, podkreślają konieczność zmiany w podejściu do edukacji.

Rada Europy, wykorzystując mandat do propagowania demokracji, ochrony praw człowieka i praworządności, od powstania w 1949 r. koncentrowała się na doradzaniu 47 państwom członkowskim w Europie w zakresie zmiany ich systemów edukacji w taki sposób, by dzieci mogły stać się aktywnymi i odpowiedzialnymi obywatelami. W 2013 r. Rada powołała międzynarodową i interdyscyplinarną grupę ekspertów w celu opracowania nienormatywnych wytycznych i wskaźników kompetencji w zakresie kultury demokratycznej i dialogu międzykulturowego, które władze krajowe oraz instytucje edukacyjne mogą wykorzystywać i dostosowywać do własnych potrzeb. Model jest oparty na wnioskach i propozycjach wielu organizacji specjalizujących się w edukacji. Został on zbudowany wokół czterech obszarów kompetencji: wartości, postaw, umiejętności i wiedzy oraz krytycznego myślenia.

Ilustracja 3. Kompetencje w zakresie kultury demokratycznej według Rady Europy

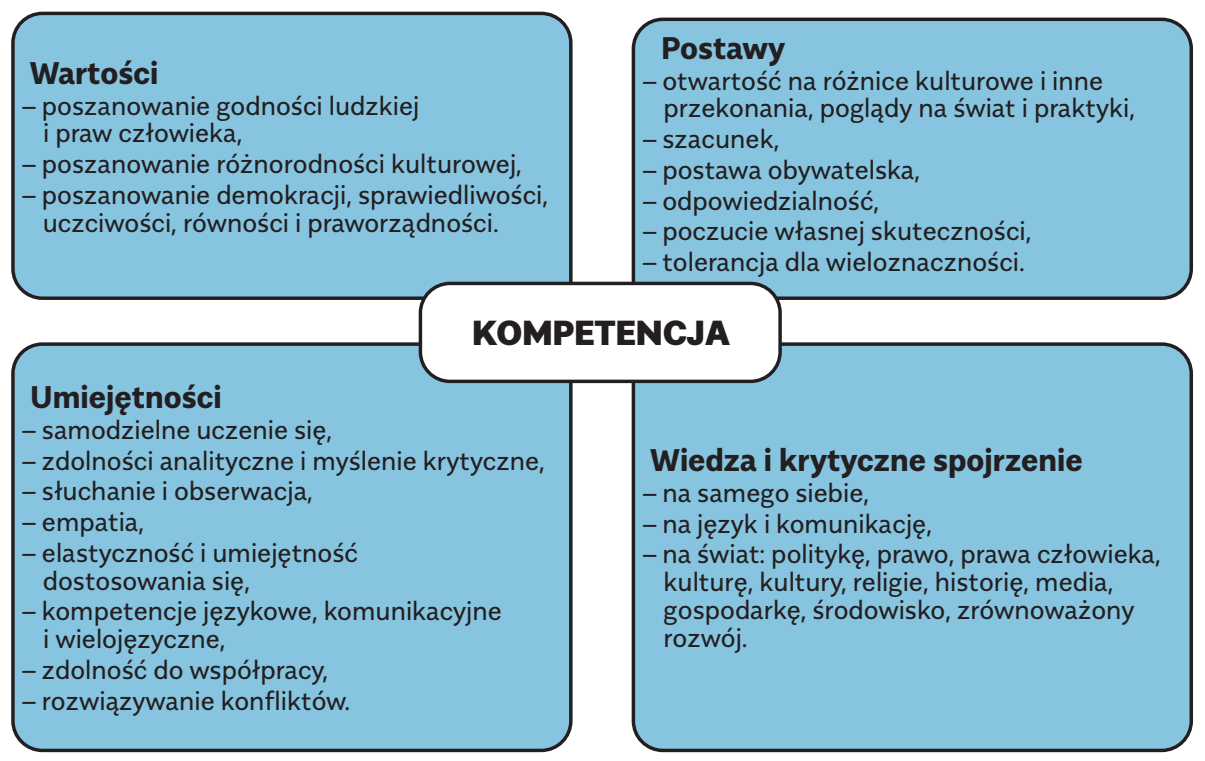


Cztery obszary modelu kompetencji odpowiadają ściśle czterem filarom Jacques'a Delorsa zdefiniowanym dwie dekady temu jako podstawa edukacji w XXI w.

Ilustracja 4. Kompetencje w zakresie obywatelstwa demokratycznego

- korelacja między modelem Jacques'a Delorsa a propozycją Rady Europy

\section{Cztery filary edukacji według Jacques’a Delorsa}
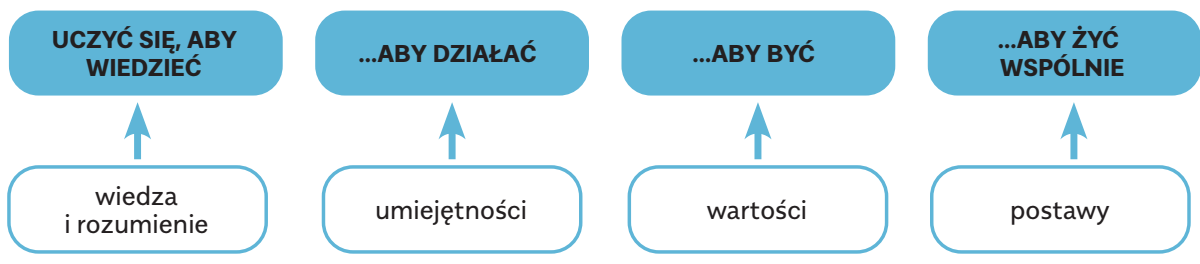

\section{Cztery obszary kompetencji według Rady Europy}

Wartości odpowiadają temu, co Jacques Delors określił mianem „uczyć się, aby być". Określenie „uczyć się, aby żyć wspólnie” można zdefiniować jako postawę, a kompetencje jej dotyczące to: szacunek, otwartość, postawa obywatelska i odpowiedzialność. Trzeci filar, czyli "uczyć się, aby działać", przekłada się na umiejętności, w tym słuchanie i obserwację, współpracę, empatię, krytyczne myślenie i rozwiązywanie konfliktów. „Uczyć się, aby wiedzieć” to wiedza i krytyczne pojmowanie kompetencji obywateli w kulturze demokratycznej. Wstępem do nich jest zrozumienie samego siebie oraz siły języka i komunikacji - to elementy niezbędne, jeśli dana osoba ma w pełni pojąć znaczenie takich wyrażeń jak zrównoważony rozwój, środowisko, kultura, gospodarka, historia i media. Wszystkie te elementy są nieodzowne w dzisiejszym świecie.

W ostatnich dwóch latach Rada Europy powołała grupę roboczą do spraw obywatelstwa cyfrowego, której zadaniem jest wpisanie kompetencji w zakresie kultury demokratycznej w ramy edukacyjne. Może to, dzięki interdyscyplinarnemu podejściu w krajowych programach nauczania w szkołach, pomóc w kształceniu młodych ludzi, aby stali się oni kompetentnymi, odpowiedzialnymi obywatelami zarówno w internecie, jak i poza nim. Fundamentalne znaczenie dla społeczeństwa, 
ale także dla samych dzieci, ma to, że kierują się one takimi wartościami jak sprawiedliwość, uczciwość, równość, prawa człowieka i godność, w miarę jak uczą się poruszać w labiryncie życia i internetu.

Opanowanie wszystkich czterech obszarów kompetencji powinno w znacznie większym stopniu przyczynić się do poprawienia samopoczucia dzieci, niż tylko zapewnić im bezpieczeństwo w sieci. Dzięki temu będą one mogły pełniej i bardziej sensownie korzystać z możliwości, jakie daje technologia cyfrowa, a także unikać nadmiernego wpływu, jaki może ona na nich wywierać. Dzieci nauczą się kształtować środowisko cyfrowe, zamiast poddawać się kształtowaniu przez technologie. Będą w stanie zrozumieć wpływ, jaki nowinki technologiczne mogą mieć na społeczeństwo lub niektóre jego sektory, zyskają ponadto większą świadomość możliwych zagrożeń, przyczyniając się tym samym do zrównoważonego rozwoju.

Młodzi ludzie stają dziś w niemal każdej dziedzinie życia wobec zupełnie innych wyzwań niż te, z jakimi mierzyły się poprzednie pokolenia. Będąc cennym zasobem zarówno dla przemysłu, jak i dla administracji rządowej i innych dostawców usług, nie muszą nawet korzystać $z$ internetu, aby ich dane były gromadzone i przechowywane, w związku z tym, że w sklepach, restauracjach i miejscach użyteczności publicznej powszechnie stosowane są karty lojalnościowe i podobne mechanizmy. Równie szybko, jak są opracowywane i wdrażane nowe przepisy, pojawiają się również innowacyjne sposoby pozyskiwania i wykorzystywania jeszcze większej ilości danych. Obecnie młodzi ludzie muszą zwracać uwagę nie tylko na bezpieczeństwo swoich danych osobowych i na ochronę prywatności, ale także dbać o interesy osób, z którymi wchodzą w interakcje (przynajmniej online).

Wyszukiwanie informacji potrzebnych do odrobienia pracy domowej było kiedyś prostym zadaniem. W dzisiejszych czasach młodzi ludzie nie mogą ufać materiałom, które można znaleźć w internecie - konieczne jest także sprawdzanie i porównywanie różnych źródeł. Muszą się oni także nauczyć, jak nie korzystać z kusząco łatwego mechanizmu "kopiuj i wklej" oraz tego, żeby nie przekazywać tweetów i fragmentów informacji, mimo ciągłego dążenia do bycia interesującym i chęci publikowania wyłącznie doskonałych treści. Poruszają się w środowisku fałszywych informacji, których liczba w internecie zwiększa się w zastraszającym tempie. 
Instytucje europejskie i organizacje międzynarodowe już od kilkudziesięciu lat starają się opracować rozwiązania edukacyjne, które wykorzystają moc technologii cyfrowych i będą propagować skuteczne umiejętności uczenia się przez całe życie wśród dzieci i młodzieży. Poszukują sposobów na wsparcie młodych ludzi stojących przed tymi i wieloma innymi wyzwaniami, budowanie ich odporności i wyposażenie ich w narzędzia, wartości, postawy, wiedzę i umiejętności, których potrzebują, aby aktywnie i w sposób pozytywny uczestniczyć w życiu społecznym. Przede wszystkim jednak chcą umożliwić budowanie etycznego społeczeństwa, w którym prawa człowieka są szanowane, a dobro społeczne nie jest wypierane przez innowacje technologiczne. Wiele z proponowanych modeli uwzględnia kwestię bezpieczeństwa w internecie, ale za pomocą strategii na tyle ogólnych, żeby można je było dostosować do pojawiających się narzędzi i uwarunkowań.

\section{Przegląd wybranych modeli edukacyjnych opartych na kompetencjach}

W 2012 r. UNESCO po raz pierwszy opublikowało Global Education Initiative (Globalną Inicjatywę Edukacyjną) jako element strategii Preparing learners for the challenges of the 21st century (Przygotowanie osób uczących się do wyzwań XXI w.). Następnie, w 2015 r., ta sama organizacja ogłosiła szczegółowe kompendium zagadnień i efektów uczenia się w ramach Global Citizenship Education (UNESCO 2015). Publikacja i struktura ramowa zawierają jasne wytyczne, które są wdrażane przez nauczycieli na całym świecie. Technologia cyfrowa została sprawnie zintegrowana z podstawowymi założeniami koncepcyjnymi, odzwierciedlając sposób, w jaki wielu z nas przechodzi obecnie ze świata rzeczywistego do wirtualnego, w zależności od zagadnienia, którym się zajmujemy, lub zadania, które realizujemy. Zostały zdefiniowane trzy podstawowe wymiary edukacji na rzecz obywatelstwa globalnego:

$\rightarrow$ poznawczy, który odnosi się do zdobywania wiedzy, rozumienia i krytycznego myślenia o sprawach globalnych, regionalnych, krajowych i lokalnych, a także do wzajemnych powiązań i współzależności różnych krajów i społeczności.

$\rightarrow$ społeczno-emocjonalny, który dotyczy poczucia przynależności do ludzkości, dzielenia się wartościami i obowiązkami, empatii, solidarności oraz szacunku dla różnic i różnorodności, 
$\rightarrow$ behawioralny, czyli zapewnienie edukacji, która pomoże uczniom działać skutecznie i odpowiedzialnie na poziomie lokalnym, krajowym i globalnym na rzecz bardziej pokojowego i zrównoważonego świata.

W tym samym czasie Wspólne Centrum Badawcze Komisji Europejskiej opublikowało model DigComp ${ }^{17}$. Jego cele były podobne do tych zaproponowanych przez UNESCO w Global Citizenship Education. Równie duży nacisk położono na jasno określone i możliwe do wykształcenia kompetencje oraz szeroki program szkoleń dla nauczycieli. Podkreślając konieczność uczenia się przez dzieci, w jaki sposób chronić się w sieci i odpowiedzialnie korzystać z technologii cyfrowych, oba modele proponują jednak nieco szersze podejście międzyprzedmiotowe, mające na celu umożliwić młodym ludziom uczenie się przez całe życie i zachęcić do krytycznego myślenia, zarówno w sieci, jak i poza nią. DigComp i kolejna wersja DigComp 2.0 wskazują pięć kluczowych komponentów, wokół których można budować szkolne programy nauczania:

1. Umiejętność korzystania z informacji i danych: wyrażanie potrzeb informacyjnych, umieszczanie i pobieranie danych cyfrowych, informacji i treści, ocenianie wiarygodności źródeł i treści, przechowywanie i organizowanie danych, informacji i treści cyfrowych oraz zarządzanie nimi.

2. Komunikacja i współpraca: wchodzenie w interakcje, komunikacja i współpraca za pośrednictwem technologii cyfrowych przy jednoczesnej świadomości różnorodności kulturowej i pokoleniowej, uczestnictwo w życiu społecznym za pośrednictwem publicznych i prywatnych usług cyfrowych oraz w ramach obywatelstwa partycypacyjnego, zarządzanie własną tożsamością i reputacją cyfrową.

3. Tworzenie treści cyfrowych: opracowywanie i edytowanie treści cyfrowych, podnoszenie jakości oraz integracja informacji i treści z istniejącymi zasobami wiedzy (przy jednoczesnym zrozumieniu tego, w jaki sposób stosować prawa autorskie i licencje), umiejętność wydawania instrukcji zrozumiałych dla systemu komputerowego. 
4. Bezpieczeństwo: ochrona urządzeń, treści, danych osobowych i prywatności w środowisku cyfrowym, ochrona zdrowia fizycznego i psychicznego oraz świadomość wpływu technologii cyfrowych na dobrostan i włączenie społeczne, świadomość wpływu technologii cyfrowych i ich stosowania na środowisko naturalne.

5. Rozwiązywanie problemów: identyfikacja potrzeb i problemów oraz rozwiązywanie problemów koncepcyjnych i sytuacji problemowych w środowisku cyfrowym, wykorzystanie narzędzi cyfrowych do wprowadzania innowacji w procesach i produktach, bycie na bieżąco z cyfrową ewolucją.

Ilustracja 5. Model edukacji DigComp 2.0 opracowany przez Komisję Europejską

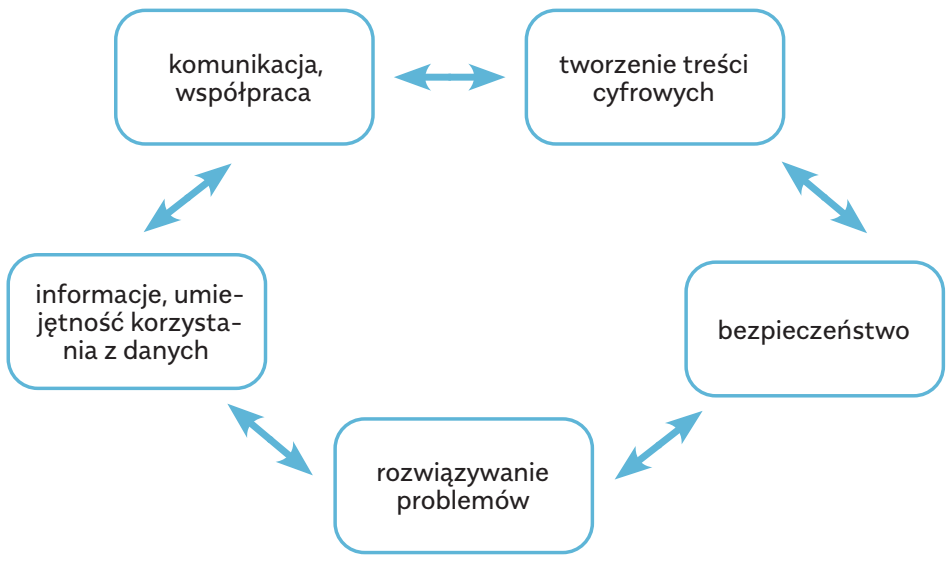

\section{Rada Europy - podejście skoncentrowane na kompetencjach i zorientowane na dziedzinie}

Wykonując mandat w zakresie ochrony praw człowieka, demokracji i praworządności, Rada Europy w centrum swoich działań stawia edukację i wzmacnianie pozycji obywateli. Ponieważ edukacja jest środkiem, za pomocą którego obywatele nabywają wiedzę, umiejętności, przekonania, nawyki i poznają wartości, potrzebne do tego, aby w pełni uczestniczyć w życiu społecznym, dziedzina ta musi być bieżąco dostosowywana do zmian zachodzących w społeczeństwie i do realiów.

Rada Europy już wcześniej opracowywała narzędzia edukacyjne i strategie na rzecz obywatelstwa cyfrowego. Jednym z przykładów jest pierwsza wersja publikacji Internet Literacy Handbook, która ukazała 
się w 2003 r. Była to seria arkuszy informacyjnych, z których każdy był poświęcony innemu narzędziu lub innej platformie internetowej. Miały one dostarczać wiedzę o tych rozwiązaniach i pokazywać konkretne przykłady ich działania. Wydawnictwo było przeznaczone dla nauczycieli, rodziców i osób odpowiedzialnych za wyznaczanie kierunków polityki. Zawierało opisy działań edukacyjnych, informacje na temat dostępnych zasobów i przykłady dobrych praktyk do wykorzystania w domu lub w szkole.

W podręczniku szczególnie podkreślono edukacyjną wartość dodaną wynikającą z wykorzystania różnego rodzaju technologii cyfrowych, a także potencjalne kwestie etyczne, które mogą być związane z każdą z nich. Już w 2003 r. publikacja łączyła kwestie edukacji obywatelskiej i bezpieczeństwa w internecie, a Rada Europy od tamtej pory niezmiennie stosuje takie podejście. Niedawno opublikowana czwarta wersja podręcznika ${ }^{18}$ porusza tak różne zagadnienia, jak dostęp i włączenie społeczne, zakupy online, sztuczna inteligencja i wyszukiwanie danych. Wszystkie wersje tworzono przez lata na podstawie podobnego schematu. Dostarczają one informacje i wskazują dobre praktyki, pozostawiając obywatelom (dobrze poinformowanym) swobodę decydowania o tym, kiedy i w jaki sposób technologia cyfrowa może być wykorzystywana właściwie i odpowiedzialnie.

Grupa robocza do spraw obywatelstwa cyfrowego, powołana przez Radę Europy w 2016 r., poszła o kilka kroków dalej i opracowała wyczerpującą klasyfikację obywatelstwa cyfrowego, z podziałem na 10 różnych dziedzin. Opierają się one na rozwoju 20 kompetencji, z jasnymi przykładami wymagań przypisanych do konkretnych dziedzin. Dziedziny podzielono na trzy główne obszary.

Publikacja Digital Citizenship Handbook, która ukaże się w 2019 r., praktycznie definiuje i opisuje każdą z 10 dziedzin oraz wiele kwestii związanych z każdą z nich. Zawarto w niej również sposoby zastosowań technologii cyfrowej oraz opinie pedagogów, rodziców i osób odpowiedzialnych za tworzenie polityki w odniesieniu do każdej dziedzin, co pozwala zapoznać się z przewidywanymi zmianami w konkretnym obszarze oraz ich potencjalnym wpływem na społeczeństwo. 
Ilustracja 6. Dziesięć dziedzin obywatelstwa cyfrowego według Rady Europy

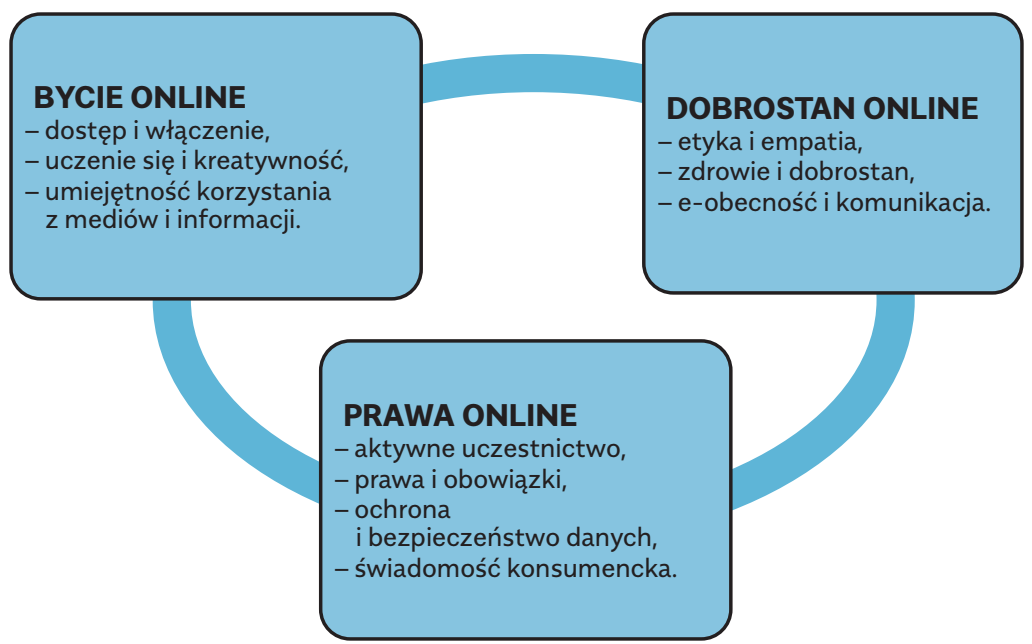

Korzystając z formatu podobnego do Internet Literacy Handbook, nakreślono edukacyjną wartość dodaną w każdej dziedzinie i zbadano potencjalne kwestie etyczne. Podręcznik zawiera listę zasobów, pomysły na pracę w klasie, dobre praktyki i sugerowane materiały referencyjne. W nadchodzących latach Rada Europy będzie stopniowo dodawać zasoby i inicjatywy w zakresie szkolenia nauczycieli oraz inne narzędzia wsparcia i ewaluacji, aby ułatwić zainteresowanym szkołom i organom publicznym ich wdrożenie.

Dwadzieścia kompetencji w zakresie kultury demokratycznej i ich analiza pod kątem dziedzin zapewnia wszechstronne, przekrojowe ramy, które można uwzględnić w nauczaniu i mierzeniu wyników. Dzięki takiemu podejściu zagadnienia dotyczące obywatelstwa cyfrowego mogą być łatwo uwzględnione w programach nauczania, szkołach i społecznościach, niezależnie od kraju czy funkcjonującego w nim systemu edukacji, zamiast stanowić tylko dodatek do edukacji, za jaki wcześniej uznawano bezpieczeństwo w internecie. $W$ ten sposób nauka o technologii cyfrowej i z jej wykorzystaniem może stać się procesem praktycznym, otwartym, możliwym do zastosowania w edukacji formalnej, nieformalnej i pozaformalnej. Otwarte procesy edukacyjne są bliższe dzisiejszemu sposobowi nauki młodych ludzi - w dowolnym miejscu i czasie. Zapewniają jednocześnie możliwości zaangażowania rodzin i społeczności. 


\section{Co niesie przyszłość?}

Technologia cyfrowa zmieniła sposób, w jaki działamy, wchodzimy w interakcje, pozyskujemy informacje i podejmujemy decyzje. Dlatego coraz ważniejsze jest, żeby każdy z nas wiedział, jak bezpiecznie, konstruktywnie i kompetentnie korzystać $z$ internetu, a także miał świadomość, że jest odpowiedzialny za podejmowane działania i zamieszczane informacje. Trzeba wziąć pod uwagę, że media społecznościowe zmieniły sposób komunikacji ludzi - zwiększyły ich potrzebę "bycia w kontakcie” i odgrywania większej roli w kształtowaniu otaczającego świata dzięki siatce powiązań społecznych.

Edukacja jest wektorem i pod pewnymi względami swoistym strażnikiem przemian społecznych, zwłaszcza w obliczu postępującego rozpadu wartości rodzinnych i społecznych, jaki można zaobserwować w społeczeństwach zachodnich. Jednocześnie technologia cyfrowa, w stopniu większym niż wcześniej, otworzyła nas na różnorodność kulturową. Jeśli wszyscy mamy odnieść korzyści ze zmian spowodowanych technologią cyfrową, to nasze systemy edukacji muszą stanąć na wysokości zadania i zacząć kształtować pewne nowe kompetencje, a także przejąć te, które wcześniej były rozwijane w rodzinie i w społeczności. Programu nauczania w szkole nie można dowolnie zmieniać. Każdy przedmiot i oczekiwany efekt edukacyjny muszą być starannie zdefiniowane i monitorowane, aby osiągały zamierzone cele. Chociaż kwestia bezpieczeństwa w internecie ma wpływ na dobro obywateli w każdym wieku, trzeba uznać, że jest to jeden z koniecznych obowiązków do realizacji przez systemy edukacji.

Edukacja na rzecz cyfrowego obywatelstwa ma sprawić, że ludzie będą wiedzieli, jak pozytywnie korzystać ze współczesnych metod komunikacji, i że zyskają kompetencje, które przyczynią się do wzmocnienia demokracji (zamiast jej osłabienia). Im więcej osób będzie zaangażowanych w poszukiwanie rozwiązań dla wyzwań wynikających z rozwoju technologii cyfrowej, tym większe będzie prawdopodobieństwo, że transformacja społeczna przyniesie korzyści większej liczbie obywateli. 
